\title{
PENGGUNAAN MODEL PEMBELAJARAN INDEX CARD MATCHUNTUK MENINGKATKAN KEMAMPUAN PENGUASAAN MATERI ALAT MUSIK TRADISIONAL ANGKLUNGPADA SISWA KELAS X TEKNIK SEPEDA MOTOR DI SMK NEGERI 3LUBUKLINGGAU
}

\author{
Lucia Listiyani \\ Guru SMKN 3 Kota Lubuklinggau \\ listiyani_lucia@yahoo.co.id
}

\begin{abstract}
This study aims at general to describe the Use of Learning Model Index Card Match To Improve The Capability Of Mastering The Material Of Traditional Musical Instrument Angklung On Student Class X Motorcycle Technique at SMK Negeri 3 Lubuklinggau. The research method used is Class Action Research (PTK), data processing does not use quantitative assessment, but using qualitative assessment. The subjects of this research are students of TSM X class. Techniques used to collect data are interviews, observation and documentation. The results of this study show that the average cycle I of 73.91 with KKM established 75. Of 32 students who completed only 17 students or $53.32 \%$ and 15 students who are not complete or $46.88 \%$. While in the second cycle obtained an average value of 92.19 with KKM set 75.Of 32 students who complete 30 students or $93.75 \%$ and 2 students who are not complete or $6.25 \%$. Then there was an increase of $40.63 \%$ from 53.12\% to 93.75\%. Bearti can be concluded that the Use of Learning Model Index Card Match To Enhance Mastery Ability of Traditional Musical Instrument Material Angklung In Students Class X Motorcycle Engineering in SMK Negeri 3 Lubuklinggau can improve student learning outcomes can be increased significantly.
\end{abstract}

Keywords:Learning Outcomes, Index Card Match Learning Model

\section{Pendahuluan}

Angklung adalah sebuah alat atau waditra kesenian yang terbuat dari bambu khusus, yang ditemukan oleh Bapak Daeng Sutigna sekitar tahun 1938. Ketika awal penggunaannya angklung masih sebatas kepentingan kesenian lokal atau tradisional.Namun karena bunyi-bunyian yang ditimbulkannya sangat merdu dan juga memiliki kandungan lokal dan internasional seperti bunyi yang bertangga nada duremi fa so la si du dan daminatilada, maka angklung pun cepat berkembang, tidak saja dipertunjukan lokal tapi juga dipertunjukan regional, nasional dan internasional.Bahkan konon khabarnya pertunjukan angklung pernah digelar dihadapan Para pemimpin Negara pada Konferensi Asia Afika di Gedung Merdeka Bandung tahun 1955.

Jumlah pemain angklung bisa dimainkan oleh sampai 50 orang, bahkan sampai 100 orang dan dapat dipadukan dengan alat musik lainnya seperti; piano, 
organ, gitar, drum, dan lain-lain. Selain sebagai alat kesenian, angklung juga bisa digunakan sebagai suvenir atau buah tangan setelah dihiasi berbagai asesoris lainnya.

Sepeninggal Daeng Sutigna kreasi kesenian angklung diteruskan oleh Mang Ujo dan Erwin Anwar.Bahkan Mang Ujo telah membuat pusat pembuatan dan pengembangan kreasi kesenian angklung yang disebut 'Saung angklung Mang Ujo" yang berlokasi di Padasuka Cicaheum Bandung. Salah satu program yang ia lakukan khususnya untuk mempertahankan kesenian angklung adalah memperkenalkan angklung kepada para siswa sekolah bahkan telah menjadi salah satu kurikulum pada pada mata pelajaran lokal.

Angklung terdaftar sebagai Karya Agung Warisan Budaya Lisan dan Nonbendawi Manusia dariUNESCO sejak November 2010.Tidak ada petunjuk sejak kapan angklung digunakan, tetapi diduga bentuk primitifnya telah digunakan dalam kulturNeolitikum yang berkembang di Nusantara sampai awal penanggalan modern, sehingga angklung merupakan bagian dari relik praHinduisme dalam kebudayaan Nusantara.

Catatan mengenai angklung baru muncul merujuk pada masa Kerajaan Sunda (abad ke-12 sampai abad ke-16). Asal usul terciptanya musik bambu, seperti angklung berdasarkan pandangan hidup masyarakat Sunda yang agraris dengan sumber kehidupan dari padi (pare) sebagai makanan pokoknya.Hal ini melahirkan mitos kepercayaan terhadap Nyai Sri Pohacisebagai lambang Dewi Padi pemberi kehidupan (hirup-hurip). Masyarakat Baduy, yang dianggap sebagai sisa-sisa masyarakat Sunda asli, menerapkan angklung sebagai bagian dari ritual mengawali penanaman padi. Permainan angklung gubrag di Jasinga, Bogor, adalah salah satu yang masih hidup sejak lebih dari 400 tahun lampau.Kemunculannya berawal dari ritus padi. Angklung diciptakan dan dimainkan untuk memikat Dewi Sri turun ke bumi agar tanaman padi rakyat tumbuh subur.

Jenis bambu yang biasa digunakan sebagai alat musik tersebut adalah bambu hitam (awi wulung) dan bambu putih (awi temen). Tiap nada (laras) dihasilkan dari bunyi tabung bambunya yang berbentuk bilah (wilahan) setiap ruas bambu dari ukuran kecil hingga besar.

Dikenal oleh masyarakat sunda sejak masa kerajaan Sunda, di antaranya sebagai penggugah semangat dalam pertempuran. Fungsi angklung sebagai pemompa semangat rakyat masih terus terasa sampai pada masa penjajahan, itu sebabnya pemerintah Hindia Belanda sempat melarang masyarakat menggunakan angklung, pelarangan itu sempat membuat popularitas angklung menurun dan hanya di mainkan oleh anak- anak pada waktu itu.

Selanjutnya lagu-lagu persembahan terhadap Dewi Sri tersebut disertai dengan pengiring bunyi tabuh yang terbuat dari batang-batang bambu yang 
dikemas sederhana yang kemudian lahirlah struktur alat musik bambu yang kita kenal sekarang bernama angklung. Demikian pula pada saat pesta panen dan seren taun dipersembahkan permainan angklung.Terutama pada penyajian Angklung yang berkaitan dengan upacara padi, kesenian ini menjadi sebuah pertunjukan yang sifatnya arak-arakan atau helaran, bahkan di sebagian tempat menjadi iringiringan Rengkong dan Dongdang serta Jampana (usungan pangan) dan sebagainya.

Dalam perkembangannya, angklung berkembang dan menyebar ke seantero Jawa, lalu ke Kalimantan dan Sumatera. Pada 1908 tercatat sebuah misi kebudayaan dari Indonesia ke Thailand, antara lain ditandai penyerahan angklung, lalu permainan musik bambu ini pun sempat menyebar di sana, leh karena itu angklung di terapkan dalam dunia pendidikan.

Pendidikan pada hakikatnya berfungsi untuk mengembangkan kemampuan untuk berkembangnya potensi siswa agar menjadi manusia yang beriman dan bertaqwa kepada Tuhan Yang Maha Esa, berakhlak mulia, sehat, berilmu, cakap, kreatif mandiri dan menjadi warga negara yang demokratis serta bertanggung jawab. ${ }^{1}$

Menurut Driyarkarya dalam Ihsan mengatakan "bahwa "pendidikan adalah upaya memanusiakan manusia muda". Sedangkan menurut Dictionary of Education dalam Ihsan menyebutkan bahwa : Pendidikan adalah proses dimana seseorang mengembangkan kemampuan sikap dan bentuk-bentuk tingkah laku lainya di dalam masyarakat di mana ia hidup, proses sosial di mana orang di hadapkan pada pengaruh lingkungan yang terpilih dan terkontrol (khususnya yang datang dari sekolah), Sehingga ia dapat memperoleh atau mengalami perkembangan kemampuan sosial dan kemampuan individu yang optimum ${ }^{3}$.

Dari pendapat di atas tersebut dapat di simpulkan bahwa pendidikan adalah proses bimbingan yang dilakukan secara sadar oleh pendidik terhadap proses perkembangan jasmani dan rohani peserta didik, dengan tujuan supaya terbentuk kepribadian yang unggul. Kepribadian yang unggul ini memiliki makna yang cukup dalam, yaitu pribadi yang bukan hanya pintar secara akademis tapi juga baik secara karakter. Dalam melakukan pendidikan membutuhkan proses belajar dan pembelajaran terutama pendidikan yang berbasis di sekolah. Belajar dan pembelajaran di sini guru di tuntut kreatif dan inovatif dalam proses pembelajaran di kelas, guru bisa menggunakan alternatif yaitu menggunakan model pembelajaran.

${ }^{1}$ Muklis Riyanto, Manajemen Kepala Sekolah Dalam Melaksanakan Supervisi Akademik (Studi Deskiptif Kualitatif di SMA Negeri 5Lubuklinggu).2015, Tesis Strata 2 Magister Administrasi Pendidikan Program Pascasarjana FKIP Universitas Bengkulu,hal.1.

${ }^{2}$ Fuad Ihsan, Dasar-dasar Kependidikan, (Jakarta: Renika Cipta, 2010),hal.4.

${ }^{3}$ Ibid. 
Tujuan dan manfaat pendidikan adalah untuk meningkatkan mutudankualitas sumber daya manusia,baikdari aspekkemampuan,kepribadian, maupuntanggung jawabsebagaiwargamasyarakat.Dalamrangkamenghadapi perkembanganilmupengetahuandanteknologiyang semangkinpesatsekarangini, bidangpendidikanharusmendapatpenanganandanprioritas yangutamabaikoleh pemerintah,para pengelola pendidikanmaupun masyarakat.Gurusebagaitenaga pendidikmempunyaitujuanutamauntukmenciptakanprestasibelajaryangoptimal yaitudengancara menciptakansuasana belajaryangmenyenangkan,dapatmenarik minatdanantusiassiswasertadapatmemotivasisiswa untuksenantiasabelajardengan baik dan semangat.

Hal tersebut sesuai denganpendapat Sukmadinatasebagai berikut: Perbuatan mendidikdiarahkan pada pencapian tujuan-tujuan tertentu, yaitu tujuan pendidikan. ${ }^{4}$ Tujuan-tujuan inibisa menyangkut kepentingan pesertadidik sendiri,kepentinganmasyarakatdantuntutan lapanganpekerjaanatau ketiga- tiganya peserta didik,masyarakatdanpekerjaansekaligus.Prosespendidikan terarahpada peningkatanpenguasaanpengetahuan,kemampuan,keterampilan, pengembangan sikap dan nilai-nilai dalam rangka pembentukan dan pengembangan diri peserta didik.

Suprijono mengatakan bahwa "model pembelajaran Index Card Match dapat memupuk kerja sama siswa dalam menjawab pertanyaan dengan mencocokkan kartu indeks yang ada di tangan mereka". 5 Proses pembelajaran ini lebih menarik karena siswa mencari pasangan sambil belajar mengenai suatu konsep atau topik dalam suasana yang menyenangkan. Dalam model ini siswa harus mengerjakan banyak tugas. Mereka harus menggunakan otak, mengkaji gagasan, memecahkan masalah, dan menerapkan apa yang mereka pelajari.

Berdasarkan latar belakang di atas, penulis tertarik untuk melakukan Penelitian Tindakan Kelas (PTK) dengan judul "Penggunaan Model Pembelajaran Index Card MatchUntuk Meningkatkan Kemampuan Penguasaan Materi Alat Musik Tradisional AngklungPada Siswa Kelas X Teknik Sepeda Motor di SMK Negeri 3Lubuklinggau".

Rumusan masalah dalam penelitian ini adalah "Apakah terjadi peningkatan dalam Penggunaan Model Pembelajaran Index Card MatchUntuk Meningkatkan Kemampuan Penguasaan Materi Alat Musik Tradisional AngklungPada Siswa Kelas X Teknik Sepeda Motor di SMK Negeri 3Lubuklinggau?".

Adapun tujuan penelitian ini adalah untuk mendeskripsikan Penggunaan Model Pembelajaran Index Card MatchUntuk Meningkatkan Kemampuan

\footnotetext{
${ }^{4}$ Sukmadinata,Metode Penelitian Pendidikan,(Bandung: Remaja Rosdakarya,2010), hal. 25.

${ }^{5}$ Agus Suprijono, Coperative Learning, Teori dan Aplikasi PAIKEM,(Yogyakarta, 2011), hal.119.
} 
Penguasaan Materi Alat Musik Tradisional AngklungPada Siswa Kelas X Teknik Sepeda Motor di SMK Negeri 3Lubuklinggau.

Hasil penelitian ini diharapkan dapat memberikan manfaat bagi berbagai pihak. Manfaat yang diharapkan dari penelitian adalah sebagai berikut: 1) Bagi siswa, sebagai pendorong siswa untuk dapat berinteraksi aktif dalam proses pembelajaran, meningkatan hasil belajar dan melatih siswa untuk berfikir kritis, logis, dan sistematis sehingga siswa dapat memahami materi yang diberikan, selalu semangat dalam mengikuti pembelajaran karena model yang dipakai menarik dan tidak membosankan, 2) Bagi suru, sebagai bentuk pengembang profesionalisme untuk melakukan inovasi dalam pembelajaran dan mengembangkan kemampuan merencanakan dan menggunakan model pembelajaran Index Card Match dalam pembelajaran materi Alat Musik Tradisional Angklung, 3) Bagi SMK Negeri 3 Lubuklinggau, penelitian ini dapat memberikan kontribusi bagi sekolah berupa perbaikan proses pembelajaran yang diharapkan meningkatkan citra sekolah dan kualitas lulusan dan sebagai masukan dalam rangka mengefektifkan pendayagunaan tenaga pendidikan untuk melaksanakan kurikulum tingkat satuan pendidikan, 4) Bagi Dinas Provinsi Sumatera Selatan, hasil penelitian diharapkan dapat dijadikan sebagai sumbangan pemikiran ilmu pengetahuan dalam mata pelajaran Seni Budaya.

\section{Metode}

Metode penelitian adalah cara yang digunakan untuk melakukan penelitian secara ilmiah menurut kaidah keilmuan. Menurut Arikunto mengatakan bahwa "metode penelitian merupakan cara utama yang digunakan peneliti untuk mencapai tujuan dan menentukan jawaban atas masalah yang diajukan". 6 Sedangkan Sugiyono mengatakan bahwa "metode penelitian merupakan cara ilmiah untuk mendapatkan data dengan tujuan dan kegunaan tertentu". Metode yang digunakan dalam penelitian ini adalah metode Penelitian Tindakan Kelas (PTK).

Penelitian tindakan kelas berasal dari istilah bahasa Inggris Classroom Action Research, yang berarti penelitian yang dilakukan pada sebuah kelas untuk mengetahui akibat tindakan yang diterapkan pada suatu subyek penelitian di kelas tersebut.Pertama kali penelitian tindakan kelas diperkenalkan oleh Kurt Lewin pada tahun 1946, yang selanjutnya dikembangkan oleh Stephen Kemmis, Robin Mc Taggart, John Elliot, Dave Ebbutt dan lainnya. hal. 51.

${ }^{6}$ SuharsimiArikunto, Dasar-Dasar Evaluasi Pendidikan, (Jakarta: Bumi Aksara, 2010), 2009),hal. 1

${ }^{7}$ Sugiyono,Metode Penelitian Kuantitatif,Kualitatif dan R\&D, (Bandung: Alfabeta, 
Pada awalnya penelitian tindakan menjadi salah satu model penelitian yang dilakukan pada bidang pekerjaan tertentu dimana peneliti melakukan pekerjaannya, baik di bidang pendidikan, kesehatan maupun pengelolaan sumber daya manusia.Salah satu contoh pekerjaan utama dalam bidang pendidikan adalah mengajar di kelas, menangani bimbingan dan konseling, dan mengelola sekolah.Dengan demikian yang menjadi subyek penelitian adalah situasi di kelas, individu siswa atau di sekolah. Para guru atau kepala sekolah dapat melakukan kegiatan penelitiannya tanpa harus pergi ke tempat lain seperti para peneliti konvensional pada umumnya.

Secara lebih luas penelitian tindakan diartikan sebagai penelitian yang berorientasi pada penerapan tindakan dengan tujuan peningkatan mutu atau pemecahan masalah pada sekelompok subyek yang diteliti dan mengamati tingkat keberhasilan atau akibat tindakannya, untuk kemudian diberikan tindakan lanjutan yang bersifat penyempurnaan tindakan atau penyesuaian dengan kondisi dan situasi sehingga diperoleh hasil yang lebih baik.

Tempat penelitian tindakan dilaksanakan di SMK Negeri 3 Lubuklinggau, adapun alasan peneliti melakukan penelitian di sekolah tersebut karena peneliti merupakan guru mata pelajaran Seni Budaya di sekolah tersebut, sehingga peneliti mengetahui dengan pasti permasalahan yang dihadapi siswa dalam mata pelajaran Seni Budaya, peneliti tindakan ini dilaksanakan dalam waktu selama dua bulan yaitu Januari dan Februari peneliti dilakukan pada semester genab tahun 2016.

Penelitian tindakan kelas ini direncanakan dua siklus dalam tiap siklusnya terdiri dari 4 (empat) tahap yaitu perencanaan, pelaksanaan, pengamatan, dan refleksi. Perencanaan dalam tahap penelitian tindakan merupakan tahap dimana peneliti akan menjelaskan tentang apa. Mengapa, kapan, dimana, oleh siapa, dan bagaimana tindakan tersebut dilakukan. Penelitian tindakan yang ideal sebetulnya dilakukan secara berpasangan antara pihak yang melakukan tindakan dan pihak yang mengamati proses jalannya tindakan. Pelaksanaan, tahap ke-2 dari penelitian tidakan yaitu pelaksanaan yang merupakan implementasi atau penerapan isi rancangan yaitu mengadakan penelitian tindakan di kelas.Pengamatan yaitu tahap ke-3 dengan melakukan kegiatan pengamatan yang dilakukan pengamat. Refleksi yaitu tahap ke-4 yang merupakan kegiatan untuk mengemukakan kembali apa yang sudah dilakukan. ${ }^{8}$

Subjek merupakan variable dalam penelitian yang akan dikenai perlakuan atau tindakan. Subjek penelitian ini adalah siswa kelas X TSM semester Genap di SMK Negeri 3 Lubuklinggau yang berjumlah 32 orang Tahun Pelajaran 2016/2017.

\footnotetext{
${ }^{8}$ SuharsimiArikunto, Dasar-Dasar Evaluasi Pendidikan, hal.11.
} 
Sebagai alat pengumpul data peneliti menggunakan pedoman observasi dan studi dokumentasi, tes yang berbentuk berbentuk pilihan ganda dan verifikasi data.Instrumen yang diperlukan dalam penelitian tindakan kelas (PTK) haruslah sejalan dengan prosedur dan langkah PTK.Instrumen untuk mengukur keberhasilan tindakan dapat dipahami dari dua sisi yaitu sisi proses dan sisi hal yang diamati yaitu lembar observasi dan angket.

Kegiatan analisis data adalah penyajian data yang diartikan sebagai kesimpulan data yang terorganisasi, sehingga memungkinkan adanya kesimpulan. Kegiatan teknik analisis data adalah untuk mengetahui persentase hasil belajar siswa, bahwa persentase siswa yang telah tuntas belajar secara klasikal dapat dirumuskan sebagai berikut :

$\mathrm{PKK}=\frac{\boldsymbol{A}}{\boldsymbol{B}} \underset{\mathbf{S}}{\mathbf{X}} 100 \%$

Keterangan :

PKK : Persentase Ketuntasan Klasikal

$\mathrm{X} \quad$ : jumlah siswa yang telah tuntas

$\mathrm{N} \quad$ : Jumlah siswa

Kriteria ketuntasan belajar siswa klasikal akan diperoleh jika dalam kelas tersebut terdapat $80 \%$ siswa yang telah mencapai 75 .

Adapun indikator keberhasilan tindakan dalam penelitian ini adalah sebagai berikut: 1) keterlibatan siswa dalam kegiatan pembelajaran yang tadinya rendah diharapkan dapat meningkat, 2)kesiapan siswa mengikuti kegiatan pembelajaran yang semula rendah, kurang berani bertanya, hanya menunggu perintah atau pertanyaan, kurang berani menduga jawaban, dan pasif, menjadi meningkat, berani bertanya, aktif bertanya, dan berani menduga jawaban; 3) siswa yang semula kurang aktif mencari/menambah materi pelajaran diluar kegiatan pembelajaran dikelas, daya serapnya rendah, setelah selesai mengikuti kegiatan pembelajaran, siswa menjadi lebih aktif mencari berbagai sumber belajar dan mencari kata-kata penting yang belum diterangkan dari berbagai sumber karena harus menuangkannya kebagan yang telah diterangkan guru, daya serap siswa meningkat dengan prestasi belajarnya lebih dari $75 \%$ siswa mencerminkan belajar tuntas.

Menurut Kunandar, pengertian dari PTK adalah sebuah bentuk kegiatan refleksi diri yang dilakukan oleh para pelaku pendidikan dalam suatu situasi kependidikan untuk memperbaiki rasionalitas dan keadilan tentang: (a)praktikpraktik kependidikan mereka, (b)pemahaman mereka tentang praktik-praktik tersebut, (c)situasi dimana praktik-praktik tersebut dilaksanakan. 
Sesuai dengan jenis penelitian yang dipilih, yaitu penelitian tindakan, maka penelitian ini menggunakan model penelitian tindakan dari Hopkins yaitu berbentuk spiral dari sklus yang satu ke siklus yang berikutnya. Setiap siklus meliputi planning (rencana), action (tindakan), observation (pengamatan), dan reflection (refleksi). Langkah pada siklus berikutnya adalah perencanaan yang sudah direvisi, tindakan, pengamatan, dan refleksi. Sebelum masuk pada siklus 1 dilakukan tindakan pendahuluan yang berupa identifikasi permasalahan. Siklus spiral dari tahap-tahap penelitian tindakan kelas.

1. Rancangan/rencana awal, sebelum mengadakan penelitian peneliti menyusun rumusan masalah, tujuan dan membuat rencana tindakan, termasuk di dalamnya instrumen penelitian dan perangkat pembelajaran.

2. Kegiatan dan pengamatan, meliputi tindakan yang dilakukan oleh peneliti sebagai upaya membangun pemahaman konsep siswa serta mengamati hasil atau dampak dari diterapkannya metode pembelajaran model discovery.

3. Refleksi, peneliti mengkaji, melihat dan mempertimbangkan hasil atau dampak dari tindakan yang dilakukan berdasarkan lembar pengamatan yang diisi oleh pengamat.

4. Rancangan/rencana yang direvisi, berdasarkan hasil refleksi dari pengamat membuat rancangan yang direvisi untuk dilaksanakan pada siklus berikutnya.

Observasi dibagi dalam dua putaran, yaitu putaran 1, 2 dan 3, dimana masing - masing putaran dikenai perlakuan yang sama (alur kegiatan yang sama) dan membahas satu sub pokok bahasan yang diakhiri dengan tes formatif di akhir masing putaran. Dibuat dalam dua putaran dimaksudkan untuk memperbaiki sistem pengajaran yang telah dilaksanakan.

\section{Hasil Dan Pembahasan}

\section{Hasil}

Penelitian Tindakan Kelas (PTK) ini dilakukan di SMK Negeri 1 Lubuklinggau dari tanggal Januari 2017 sampai dengan 30 Februari 2017. Dengan Subjek yaitu siswa kelas X Pemasaran 2 SMK Negeri 1 Lubuklinggau dengan jumlah 32 siswa. Sebelum melakukan kegiatan pembelajaran menmggunakan model pembelajaran Index Card Match, terlebih dahulu diberikan tes awal yang bertujuan untuk mengetahui kemampuan awal siswa dalam memahami pelajaran Seni Budaya khususnya pokok bahasan operasi Alat Musi Tradisional Angklung, karena kemampuan awal ini sangat diperlukan untuk pemahaman materi selanjutnya yang menjadi fokus penelitian ini.

Seorang siswa dikatakan telah tutas belajar atau berhasil apabila telah mencapai nilai Kriteria Ketuntasan Minimal (KKM) untuk pelajaran Seni Budaya yaitu 75. Sedangkan hasil tes kemampuan awal siswa kelas X SMK Negeri 3 Lubuklinggau dapat dilihat pada lampiran. 
Tabel 4.1

Rekapitulasi hasil belajar siswa sebelum tindakan

$\begin{array}{ccccc}\text { No } & \text { Siswa } & \text { Persentase } & \text { Nilai Rata-rata } & \text { KKM } \\ 1 & 3 \text { Tuntas } & 9.38 \% & 50.16 & 75 \\ 2 & 29 \text { Tidak Tuntas } & 90.62 \% & & \\ \text { Jumlah } & 32 \text { Siswa } & 100 \% & & \end{array}$

Dari tabel pada lampiran tersebut terlihat bahwa dari hasil tes sebelum tindakan terdapat 3 siswa dari 32 siswa yang tuntas belajar atau sebesar $9.38 \%$ dan 29 siswa dari 32 siswa yang belum tuntas belajar atau sebesar $90.62 \%$ dengan nilai rata-rata 50.16 pada KKM yang ditetapkan sebesar 75 .

1. Hasil Siklus Pertama

Pada siklus pertama ini peneliti melakukan kegiatan belajar mengajar pada materi menyimak pada satu kali pertemuan dengan menggunakan model pembelajarn Index Card Matchyang di lakukan pada proses pembelajaran di kelas $\mathrm{X}$ TSM yang ber jumlah 32 siswa.

a. Aktifitas Guru

Data hasil pengamatan aktivitas selama proses pembelajaran berlangsung dapat dilihat pada tabel 4.2 dibawah ini sebagai berikut:

Tabel 4.2

Aktivitas yang dilaksanakan guru pada Siklus Pertama

No

Aspek Yang Diamati

Dilaksanakan

1 Menyampaikan tujuan pembelajaran

2 Memotovasi siswa dalam melakukan pembelajaran

3 Memberikan tugas secara individu

4 Memberikan bimbingan dan pengawan terhadap siswa

5 Memberikan dorongan kepada siswa sehingga siswa mau bekerja dalam menyelesaikan tugas-tugas yang diberikan

6 Mendiskusikan hasil dari tugas-tugas yang dikerjakan 
7 Membantu siswa dalam menjawab pertanyaan-pertanyaan yang sulit

$8 \quad$ Membantu siswa untuk membuat kesimpulan dari materi yang didiskusikan

$9 \quad$ Memberiak tes akhir secara tertulis

Dilaksanakan

Tidak Dilaksanakan

Pada Siklus pertama dari 9 aktivitas guru dalam proses pembelajaran berlangsung hanya hanya 7 aktivitas yang dilaksanakan atau $77.78 \%$ dan 2 aktivitas tidak dilaksanakan atau 22.22\%. Sedangkan model pembelajaran yang digunakan dalam pembelajaran adalah model pembelajaran Index Card Match dengan langkah-langkah sebagai berikut:

1) Guru membuat potongan-potongan kartu sebanyak jumlah siswa yang ada di dalam kelas.

2) Guru membagi potongan kartu-kartu tersebut menjadi dua bagian yang sama.

3) Pada separuh bagian potongan kartu-kartu, guru menuliskan pertanyaan tentang materi yang akan dipelajari. Setiap kartu berisi satu pertanyaan.

4) Pada separuh kartu yang lain, guru menuliskan jawaban dari pertanyaanpertanyaan yang telah dibuat.

5) Guru mengocok semua kartu sehingga akan tercampur antara pertanyaan dan jawaban.

6) Guru membagikan satu kartu kepada setiap siswa. Guru selanjutnya menjelaskan bahwa ini adalah aktivitas yang dilakukan berpasangan. Separuh dari jumlah siswa akan mendapatkan pertanyaan dan separuh yang lain akan mendapatkan jawaban.

7) Guru meminta kepada siswa untuk menemukan pasangan mereka. Jika ada yang sudah menemukan pasangan, guru meminta kepada mereka untuk duduk berdekatan. Guru juga menjelaskan agar mereka tidak memberitahu materi yang mereka dapatkan kepada teman yang lain.

8) Setelah semua siswa menemukan pasangan dan duduk berdekatan, guru meminta kepada setiap pasangan secara bergantian untuk membacakan pertanyaan yang diperoleh dengan keras kepada teman-temannya yang lain. Selanjutnya pertanyaan tersebut dijawab oleh pasangannya.

9) Guru mengakhiri proses ini dengan membuat klarifikasi dan kesimpulan.

b. Aktifitas Siswa 
Pada hasil pengamatan terhadap jumlah siswa yang melaksanakan aktivitas selama proses pembelajaran berlangsung dapat di lihat pada tabel 4.3 di bawah ini:

Tabel 4.3

Jumlah Siswa Yang Melakukan Aktivitas Pada Siklus Pertama

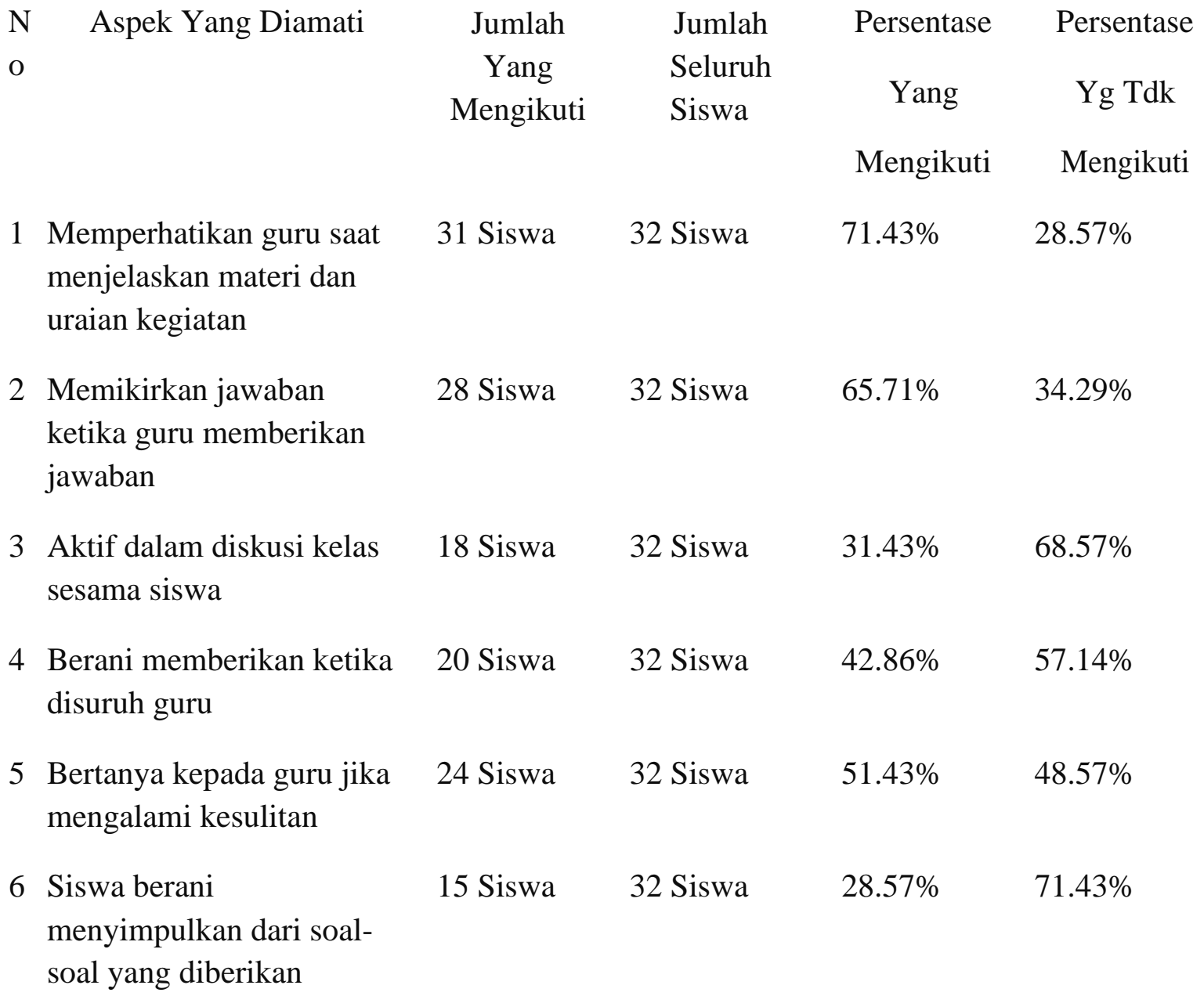

Pada pengamatan di atas dapat dilihat bahwa aktivitas siswa selama pembelajaran Matematika pada materi matriks dengan menggunakan model Index Card Matchwo yang memperhatikan rata-tata tidak mencapai $80 \%$.Hal ini bearti harus di lanjutkan ke siklus berikutnya.

c. Hasil Belajar Siswa

Setelah pembelajaran siklus pertama selesai maka diadakan evaluasi pada materi menyimak yang terdiri dari 20 soal berbentuk Pilihan Ganda. Tes tersebut diikuti dari 32 siswa kelas X TSM di SMK Negeri 1 Lubuklinggau, hal ini dapat dilihat dilampiran dan tabel 4.4 di bawah ini: 
Tabel 4.4

\begin{tabular}{ccccc} 
& \multicolumn{3}{c}{ Rekapitulasi hasil belajar siswa Siklus I } & \\
No & Siswa & Persentase & Nilai Rata-rata & KKM \\
1 & 17 Tuntas & $53.13 \%$ & 73.91 & 75 \\
2 & 15 Tidak Tuntas & $46.88 \%$ & & \\
Jumlah & 32 & $100 \%$ &
\end{tabular}

Berdasarkan tabel di atas hasil belajar siswa pada siklus pertama diperoleh nilai rata-rata 73.91 dengan KKM yang ditetapkan 75. Dari 32 siswa yang tuntas hanya 17 siswa atau $53.13 \%$ dan 15 siswa yang tidak tuntas atau $46.88 \%$.

Dengan demikian maka siswa belum dapat memahai materi yang diajarkan yaitu tentang matriks dan harus di lanjutkan ke siklus II. Berdasarkan hasil penelitian pada Siklus I, peneliti menemukan beberapa kelemahan-kelemahan dalam menggunakan model pembelajaran Index Card Match yaitu sebagai berikut :

1) Metode Pembelajaran Index Card Match yaitu membutuhkan waktu yang lama bagi siswa untuk menyelesaikan tugas dan prestasi,

2) guru harus meluangkan waktu yang lebih,

3) lama untuk membuat persiapan,

4) guru harus memiliki jiwa demokratis dan keterampilan yang memadai dalam hal pengelolaan kelas,

5) menuntut sifat tertentu dari siswa atau kecenderungan untuk bekerja sama dalam menyelesaikan masalah,

6) suasana kelas menjadi gaduh sehingga dapat mengganggu kelas.

Berdasarkan kelemahan-kelemahan tersebut, maka peneliti melanjutkan tindakan kelas pada siklus yang kedua dengan melakukan perbaikan-perbaikan diantaranya:

a) Guru mengajarkan kepada siswa tidak terlalu tergantung pada guru, tapi dapat menambah kepercayaan kemampuan berfikir sendiri,

b) Mengembangkan kemampuan mengungkapkan ide atau gagasan dengan katakata secara verbal dan membandingkan ide-ide atau gagasan orang lain,

c) Membantu anak agar dapat bekerja sama dengan orang lain, dan menyadari segala keterbatasannya serta menerima segala kekurangannya,

d) Membantu siswa untuk lebih bertanggung jawab dalam melaksanakan tugasnya,

e) Meningkatkan motivasi dan memberikan rangsangan untuk berfikir. 


\section{Hasil Siklus Kedua II}

Pada siklus kedua ini peneliti melakukan kegiatan belajar mengajar pada tidak jauh berbeda dengan siklus pertama. Pembelajaran di kelas X Pemasaran 2 yang ber jumlah 44 siswa jumlah nya juga sama dengan siklus pertama.

a. Aktifitas Guru

Data hasil pengamatan aktivitas selama proses pembelajaran berlangsung dapat dilihat pada tabel 4.5 dibawah ini sebagai berikut:

\section{Tabel 4.5}

Aktivitas yang dilaksanakan guru pada Siklus Kedua

No

Aspek Yang Diamati

Dilaksanakan

1 Menyampaikan tujuan pembelajaran

2 Memotovasi siswa dalam melakukan pembelajaran

3 Memberikan tugas secara individu

$4 \quad$ Memberikan bimbingan dan pengawan terhadap siswa

$5 \quad$ Memberikan dorongan kepada siswa sehingga siswa mau bekerja dalam menyelesaikan tugas-tugas yang diberikan

6 Mendiskusikan hasil dari tugas-tugas yang dikerjakan

$7 \quad$ Membantu siswa dalam menjawab pertanyaan-pertanyaan yang sulit

8 Membantu siswa untuk membuat kesimpulan dari materi yang

didiskusikan

$9 \quad$ Memberiak tes akhir secara tertulis

Dilaksanakan

Tidak Dilaksanakan

Pada Siklus Kedua dari 9 aktivitas guru dalam proses pembelajaran berlangsung aktivitas yang dilaksanakan $100 \%$, sedangkan model pembelajaran yang digunakan dalam pembelajaran adalah model pembelajaran Index Card Matchdengan langkah-langkah sebagai berikut:

1) Guru membuat potongan-potongan kartu sebanyak jumlah siswa yang ada di dalam kelas. 
2) Guru membagi potongan kartu-kartu tersebut menjadi dua bagian yang sama.

3) Pada separuh bagian potongan kartu-kartu, guru menuliskan pertanyaan tentang materi yang akan dipelajari. Setiap kartu berisi satu pertanyaan.

4) Pada separuh kartu yang lain, guru menuliskan jawaban dari pertanyaanpertanyaan yang telah dibuat.

5) Guru mengocok semua kartu sehingga akan tercampur antara pertanyaan dan jawaban.

6) Guru membagikan satu kartu kepada setiap siswa. Guru selanjutnya menjelaskan bahwa ini adalah aktivitas yang dilakukan berpasangan. Separuh dari jumlah siswa akan mendapatkan pertanyaan dan separuh yang lain akan mendapatkan jawaban.

7) Guru meminta kepada siswa untuk menemukan pasangan mereka. Jika ada yang sudah menemukan pasangan, guru meminta kepada mereka untuk duduk berdekatan. Guru juga menjelaskan agar mereka tidak memberitahu materi yang mereka dapatkan kepada teman yang lain.

8) Setelah semua siswa menemukan pasangan dan duduk berdekatan, guru meminta kepada setiap pasangan secara bergantian untuk membacakan pertanyaan yang diperoleh dengan keras kepada teman-temannya yang lain. Selanjutnya pertanyaan tersebut dijawab oleh pasangannya.

9) Guru mengakhiri proses ini dengan membuat klarifikasi dan kesimpulan.

b. Aktifitas Siswa

Pada hasil pengamatan terhadap jumlah siswa yang melaksanakan aktivitas selama proses pembelajaran berlangsung dapat di lihat pada tabel $4.6 \mathrm{di}$ bawah ini:

Tabel 4.6

Jumlah Siswa Yang Melakukan Aktivitas Pada Siklus Kedua

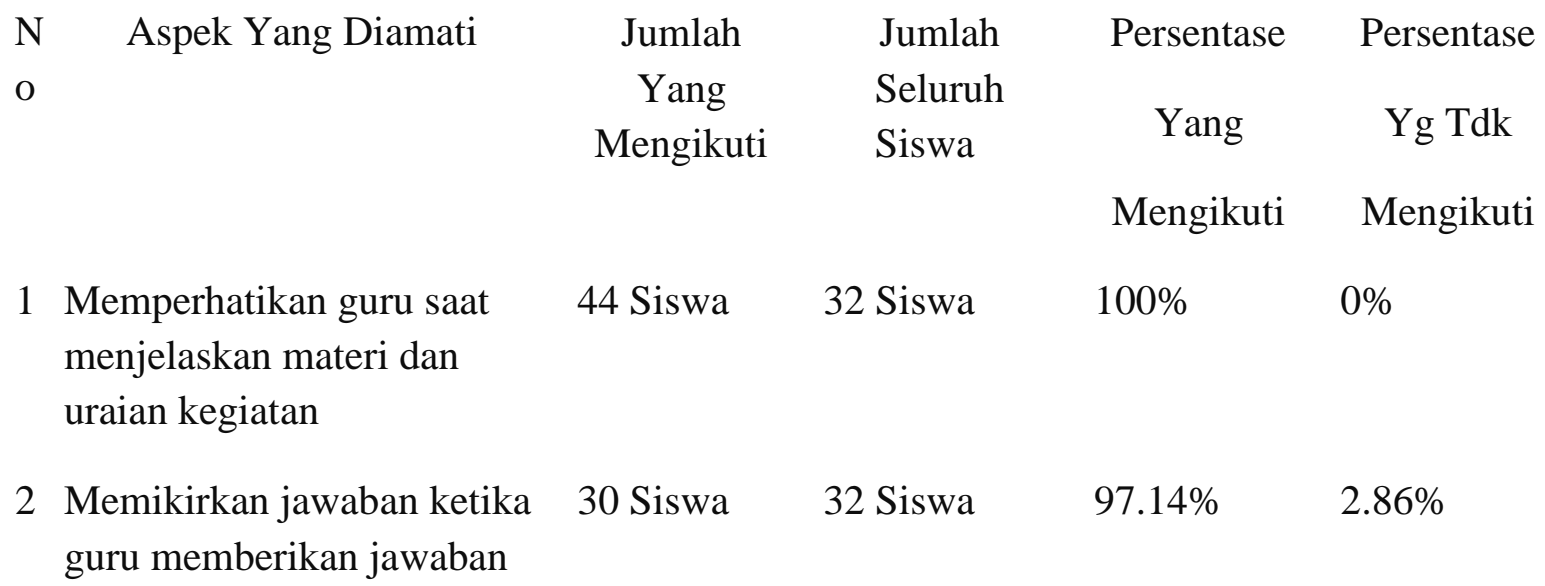


3 Aktif dalam diskusi kelas $\quad 29$ Siswa $\quad 32$ Siswa $\quad 85.74 \% \quad 14.26 \%$ sesama siswa

4 Berani memberikan ketika $\quad 29$ Siswa $\quad 32$ Siswa $\quad 85.74 \% \quad 14.26 \%$ disuruh guru

5 Bertanya kepada guru jika 28 Siswa $\quad 32$ Siswa $\quad 80 \% \quad 20 \%$ mengalami kesulitan

6 Siswa berani menyimpulkan 27 Siswa $\quad 32$ Siswa $\quad 71.43 \% \quad 28.57 \%$ dari soal-soal yang diberikan

Pada pengamatan di atas dapat dilihat bahwa aktivitas siswa selama pembelajaran Matematika pada materi menyimak dengan menggunakan model Index Card Matchyang memperhatikan rata-tata sudah mencapai 80\% lebih. Hal ini bearti terjadi peningkatan yang signifikan terhadap aktivitas siswa.

\section{c. Hasil Belajar Siswa}

Setelah pembelajaran siklus pertama selesai maka diadakan evaluasi pada materi operasi matriks yang terdiri dari 20 soal berbentuk pilihan ganda. Tes tersebut diikuti dari 32 siswa kelas X TSM di SMK Negeri Lubuklinggau, hal ini dapat dilihat dilampiran dan tabel 4.7 di bawah ini:

Tabel 4.7

\section{Rekapitulasi Hasil Belajar Siswa Pada Siklus Kedua}

$\begin{array}{ccccr}\text { No } & \text { Siswa } & \text { Persentase } & \text { Nilai Rata-rata } & \text { KKM } \\ 1 & 30 \text { Tuntas } & 93.75 \% & 92.19 & 75 \\ 2 & 2 \text { Tidak Tuntas } & 6.25 \% & & \\ \text { Jumlah } & 32 & 100 \% & \end{array}$

Berdasarkan tabel di atas hasil belajar siswa pada siklus kedua diperoleh nilai rata-rata 92.19 dengan KKM yang ditetapkan 75. Dari 32 siswa yang tuntas mencapai 32 siswa atau $93.75 \%$ dan 2 siswa yang tidak tuntas atau $6.25 \%$. Dengan demikian maka terjadi peningkatan secara signifikan hasil belajar siswa dari sebelum tindakan ke siklus I dan di lanjutkan ke siklus II karena hasil belajar siswa $93.75 \%$ dinyatakan tuntas.

\section{Pembahasan}

Dari hasil tes sebelum tindakan terdapat 3 siswa dari 32 siswa yang tuntas belajar atau sebesar $90.62 \%$ dan 29 siswa dari 32 siswa yang belum tuntas belajar 
atau sebesar $90.62 \%$ dengan nilai rata-rata 50.16 pada KKM yang ditetapkan sebesar 75 .

Pada pembelajaran Siklus I yang menggunakan model Index Card Matchmasih banyak permasalahan-permasalahan diantaranya bisa terjadi adanya pandangan dari berbagai sudut bagi masalah yang dipecahkan, bahkan mungkin pembicaraan menjadi menyimpang, sehingga memerlukan waktu yang panjang, adanya pembagian kelompok secara berpasang-pasangan dan sering antar pasangan membuat pembelajaran kurang kondusif, adanya kelompok, siswa yang kurang bertanggung jawab dalam tugas, membuat mereka lebih mengandalkan pasangannya.

Berdasarkan permasalahan-permasalahan tersebut, maka peneliti melanjutkan tindakan kelas pada siklus yang kedua dengan melakukan perbaikanperbaikan diantaranya: Guru mengajarkan kepada siswa tidak terlalu tergantung pada guru, tapi dapat menambah kepercayaan kemampuan berfikir sendiri. Mengembangkan kemampuan mengungkapkan ide atau gagasan dengan kata-kata secara verbal dan membandingkan ide-ide atau gagasan orang lain. Membantu anak agar dapat bekerja sama dengan orang lain, dan menyadari segala keterbatasannya serta menerima segala kekurangannya. Membantu siswa untuk lebih bertanggung jawab dalam melaksanakan tugasnya.Meningkatkan motivasi dan memberikan rangsangan untuk berfikir.

Pada siklus ini diperoleh nilai rata-rata 73.91 dengan KKM yang ditetapkan 75. Dari 32 siswa yang tuntas hanya 17 siswa atau 53.32\% dan 15 siswa yang tidak tuntas atau $46.88 \%$. Dengan demikian maka dapat disimpulkan bahwa pembelajaran pada siklus pertama tidak berhasil.

Sedangkan pada siklus kedua diperoleh nilai rata-rata 92.19 dengan KKM yang ditetapkan 75. Dari 32 siswa yang tuntas mencapai 30 siswa atau $93.75 \%$ dan 2 siswa yang tidak tuntas atau $6.25 \%$. Maka terjadi peningkatan sebesar 40.63\% dari $53.12 \%$ sampai $93.75 \%$.Rekapitulasi seluruh nilai dari sebelum tindakan kesiklus I dan dilanjutkan kesiklus II dapat di lihat ketabel 4.8.

Tabel 4.8

Rekapitulasi Hasil Belajar Siswa Sebelum Tindakan, Siklus I dan Siklus II

$\begin{array}{llll}\text { Keterangan Siswa } & \text { Sebelum Tindakan } & \text { Siklus I } & \text { Siklus II } \\ \text { Tuntas } & 9.38 \% & 53.12 \% & 93.75 \% \\ \text { Tidak Tuntas } & 90.68 \% & 46.88 \% & 6.25 \% \\ \text { Nilai Rata-rata } & 50.16 & 73.91 & 92.19\end{array}$


Dengan demikian maka terjadi peningkatan secara signifikan hasil belajar siswa.Sehinggadapat disimpulkan bahwa hasil belajar siswa dinyatakan berhasil.

\section{Simpulan dan Saran \\ Simpulan}

Berdasarkan hasil penelitian dan pembahasan dapat di simpulkan bahwa

terjadi peningkatan dalam Penggunaan Model Pembelajaran Index Card MatchUntuk Meningkatkan Kemampuan Penguasaan Materi Alat Musik Tradisional AngklungPada Siswa Kelas X Teknik Sepeda Motor di SMK Negeri 3Lubuklinggau". Dibuktikan dengan nilai rata-rata siklus I sebesar 73.91 dengan KKM yang ditetapkan 75. Dari 32 siswa yang tuntas hanya 17 siswa atau 53.32\% dan 15 siswa yang tidak tuntas atau 46.88\%. Sedangkan pada siklus kedua diperoleh nilai rata-rata 92.19 dengan KKM yang ditetapkan 75. Dari 32 siswa yang tuntas mencapai 30 siswa atau $93.75 \%$ dan 2 siswa yang tidak tuntas atau 6.25\% . Maka terjadi peningkatan sebesar $40.63 \%$ dari $53.12 \%$ sampai $93.75 \%$. Bearti dapat disimpulkan bahwa Penggunaan Model Pembelajaran Index Card MatchUntuk Meningkatkan Kemampuan Penguasaan Materi Alat Musik Tradisional AngklungPada Siswa Kelas X Teknik Sepeda Motor di SMK Negeri 3Lubuklinggau dapat meningkatkan hasil belajar siswa.

\section{Saran}

Berdasarkan hasil penelitian yang dilakukan, dapat dikemukakan beberapa saran sebagai berikut :

1. Siwa, diharapkan dapat terus meningkatkan semangat belajar dan lebih giat lagi belajar.

2. Guru, diharapkan dapat menggunakan model Index Card Match sebagai alternatif dalam meningkatkan hasil belajar khususnya pada mata pelajaran Matematika khususnya materi operasi matriks.

3. SMK Negeri 3 Lubuklinggau, tempat peneliti semoga dapat menerapkan model pembelajaran yang telah diterapkan, yaitu model pembelajaran Index Card Match.

\section{Daftar Pustaka}

Arikunto, Suharsimi,Prosedur Penelitian Suatu Pendekatan Praktik. Jakarta: Rineka Cipta, 2006 2010

http://tugassekolahbermanfaat.blogspot.com/2014/12/seni-rupa-3-dimensi.html http://meimpunelecessit.blogspot.com/2014/06/seni-rupa-tiga-dimensi-selainmemiliki.html

http://www.mikirbae.com/2014/01/seni-rupa-tiga-dimensi.html Ihsan, Fuad,Dasar-dasar Kependidikan. Jakarta: Renika Cipta, 2010 
Riyanto, Muklis,Manajemen Kepala Sekolah Dalam Melaksanakan Supervisi Akademik (Studi Deskiptif Kualitatif di SMA Negeri 5Lubuklinggu).2015, Tesis Strata 2 Magister Administrasi Pendidikan Program Pascasarjana FKIP Universitas Bengkulu

Sugiyono,Metode Penelitian Kuantitatif,Kualitatif dan R\&D. Bandung: Alfabeta, 2009 